\title{
IMMOBILIZATION OF PHENYLALANINE AMMONIA-LYASE ON HYDROXYAPATITE AND HYDROXYAPATITE COMPOSITES
}

\author{
JUDITH-HAJNAL BARTHA-VARI ${ }^{\mathrm{a}}$, RENÁTA ELEKES-DARABONT ${ }^{\mathrm{a}}$, \\ LAURA-EDIT BARABÁS ${ }^{a}$, RÉKA BARABÁS ${ }^{a, *}$
}

\begin{abstract}
A new and efficient immobilization method of phenylalanine ammonia-lyase was obtained using hydroxyapatite (HAP) and hydroxyapatite carbon nanotube, gelatin and chitosan - composites (HAP-CNT, HAP-GEL and HAP-CS) as support material. HAP and HAP composites were characterized by transmission electron microscopy (TEM), laser diffraction particle size analyzer and XRD measurements. The obtained nanobioconjugates were tested in the ammonia elimination reactions from $L-p h e n y l a l a n i n e(L-1)$. The reusability and the time-course profile of the immobilized enzyme preparation was also tested. While the biocatalyst obtained by using HAP-CS-15 as support material provided the highest conversion rate in the ammonia elimination reaction from L-1 $(98,1 \%$ compared to $98,5 \%$ obtained using the non-immobilized enzyme), the most stable biocatalyst proved to be HAP-PAL, which maintained more than $80 \%$ of its initial activity even after 5 cycles of reuse.
\end{abstract}

Keywords: hydroxyapatite, composites, carbon nanotubes, gelatin, chitosan, phenylalanine ammonia-lyase, immobilization, ammonia elimination

\section{INTRODUCTION}

Due to the increasing interest for natural resources and reduced pollution, biocatalytic routes are gaining more importance [1]. Enzymes are obtained from renewable sources, they are biocompatible, thus the enzymatic processes are cost effective and environmentally friendly [2]. However, their application on industrial scale is hampered by their instability and difficulty of retain and reuse [3]. These drawbacks can be overcome by immobilization, when biocatalysts with improved stability and reusability are obtained [4].

\footnotetext{
a Babeş-Bolyai University, Faculty of Chemistry and Chemical Engineering, 11 Arany Janos str., RO-400028, Cluj-Napoca, Romania,

*Corresponding author: breka@chem.ubbcluj.ro
} 
Hydroxyapatite (HAP) is the principal mineral component of bone [5]. HAP has unique properties as biocompatibility, bioactivity, osteoconductivity and affinity to biopolymers [6]. Due to its biocompatibility and structural similarity with human hard tissue its widely used as inorganic biomaterial [7]. It founds applications in drug delivery [8], biomedicine [9] or medical devices [10]. Their use is however hampered by their poor fracture toughness and resistance. HAPs mechanical properties can be improved with materials such as carbon nanotubes [11], graphene oxide [12], gelatin [13], or chitosan [14].

Ammonia-lyases are acting on $\mathrm{C}-\mathrm{N}$ bonds and catalyse the formation of $\alpha, \beta$ unsaturated bonds by elimination of ammonia from their substrates [15]. Phenylalanine ammonia-lyases (PAL EC 4.3.1.24, EC 4.3.1.25) are homotetrameric enzymes performing the non-oxidative deamination of L-phenylalanine into (E)-cinnamic acid [16] (Scheme 1). Cinnamic acid is the precursor of various phenylpropanoids, such as lignins, flavonoids and coumarins [17]. These derivatives are also widely used in cosmetics [18]. Several immobilized PAL preparates have been reported on various support materials [19] [20] [21]. Our previous successful immobilization of PcPAL on carboxylated and aminated carbon nanotubes drove our interest to the immobilization of the same enzyme on hydroxyapaptite and its composites. These support materials could present a promising alternative, since they are cost effective and environmentally friendly.

In this study our aim was the immobilization of phenylalanine ammonia-lyase from Petroselinum crispum (PcPAL) on HAP and HAP composites obtained with carbon nanotubes (HAP-CNT), gelatin (HAP-GEL) and chitosan (HAP-CH), and to test the stability and reusability of the obtained nanobioconjugates. There are several studies which reported the immobilization of enzymes on HAP and HAP composites [22],[23],[24], but according to our knowledge the immobilization of PCPAL on these materials has not been investigated.

\section{RESULTS AND DISCUSSION}

The aim of the study was the immobilization of PCPAL on hydroxyapatite (HAP) and HAP composites obtained by using carbon naotubes (HAP-CNT), gelatine (HAP-GEL) and chitosan (10, 15 and 20\%) (HAP-CS-10, HAP-CS15 and HAP-CS-20), and testing the activity and stability of the obtained immobilized enzyme preparations.

The immobilized enzymes were tested in the ammonia elimination reaction from L-phenylalanine, L-1 (Scheme 1). 
<smiles>N[C@@H](Cc1ccccc1)C(=O)O</smiles>

L-1

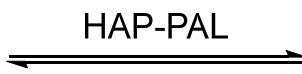

Scheme 1. PAL immobilized on hydroxyapatite and its composites for ammonia elimination reaction from L-phenylalanine

\section{Preparation of HAP and HAP based nanocomposites}

HAP and HAP composites were obtained by coprecipitation, the most straightforward and frequently used method for the preparation of these materials [25].

Even though being used on a large scale, HAPs poor tensile strength and fracture toughness makes it unsuitable for a wide range of applications. HAPs mechanical structures can be improved by using different additives, such as carbon nanotubes, gelatin or chitosan [26], [27]. Due to the CNTs excellent mechanical properties, HAP can be toughen and strengthen [28].

HAP-gelatin composites have high porosity and interconnectivity, great biocompatibility and good mechanical properties [29].

The polymeric composites of HAP have improved properties, including modulus, strength and stiffness compared to pure HAP [30]. The HAP/chitosan composites are good candidates for tissue engineering, bone and cartilage scaffolds [31].

\section{Characterization of the support material}

\section{Particle size distribution}

Several characteristics, such as chemical reactivity, opacity, texture, viscosity, density, porosity or material strength of materials are affected by the size of their particles [32]. The particle size and surface area greatly influence the properties of HAP. Depending on the growth conditions the particle size of HAP is usually between 10 and $500 \mathrm{~nm}$ [33].

The particle size of the obtained HAP and HAP composites was determined by laser diffraction particle size analyzer.

By adding the additives to the HAP a slight increase of the particle size can be observed. This could be due to the ease of aggregation of the particles in presence of polymers. The smallest particles are obtained by using carbon nanotubes as additive (Fig. 1). 


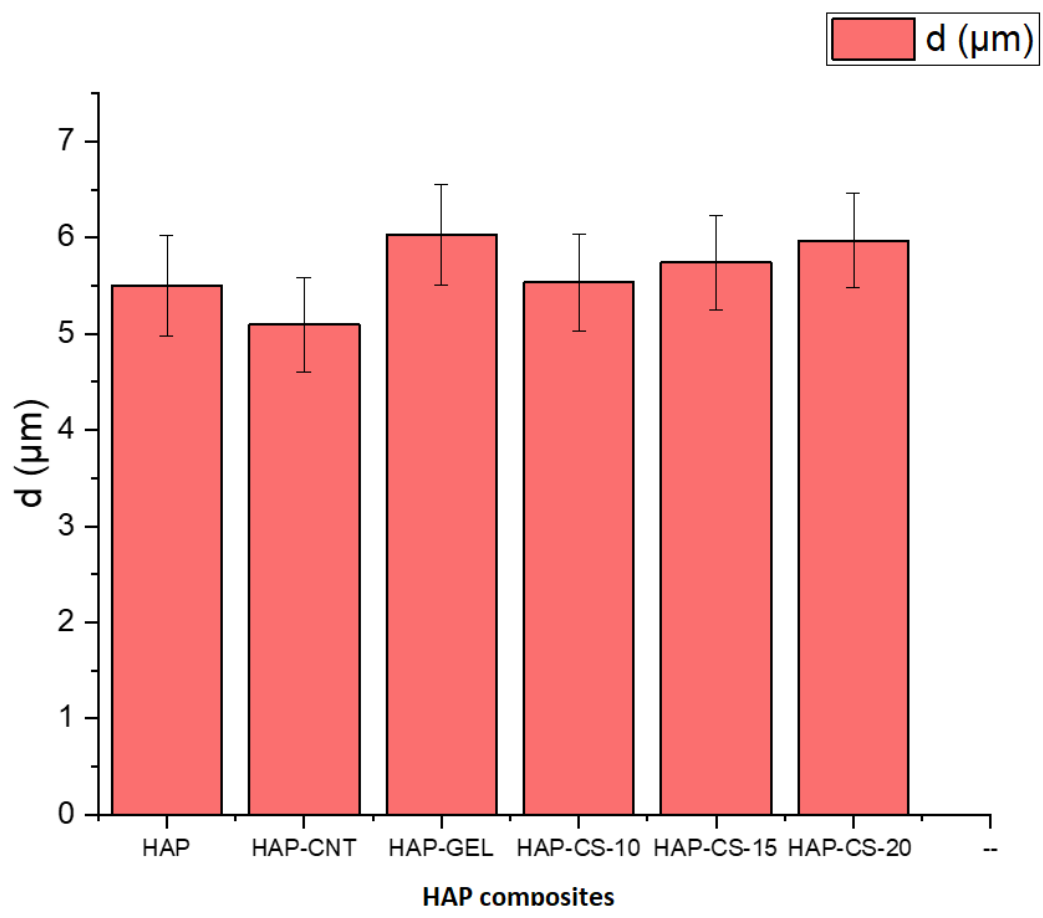

Figure 1. Particle size distribution of HAP and HAP-composites

\section{Transmisson electron microscopy (TEM)}

The morphology of the obtained composites was examined by transmission electron microscopy. As expected, in case of the HAP (Fig. 2 (1)) a good homogeneity can be observed, property which characterizes this support. The carbon nanotube particles are integrated between the HAP crystals (Fig. 2 (2)). The composites obtained by the addition of gelatin (Fig. 2 (3)) and chitosan Fig 2 (4), (5), (6)), loses the prism shape characteristic to HAP, instead they have a round shape. Thus, the gelatin and chitosan have a strong influence upon the morphology of the composites, they disable the formation of the crystals. The morphology and the size distribution in case of HAP-CS are evan. A difference between the HAP (Fig. 2 (1)) and HAP coated by APTES (Fig. 2 (7)) can also be observed on the TEM images, since APTES creates a silica coating of HAP. 
IMMOBILIZATION OF PHENYLALANINE AMMONIA-LYASE ON HYDROXYAPATITE AND ...

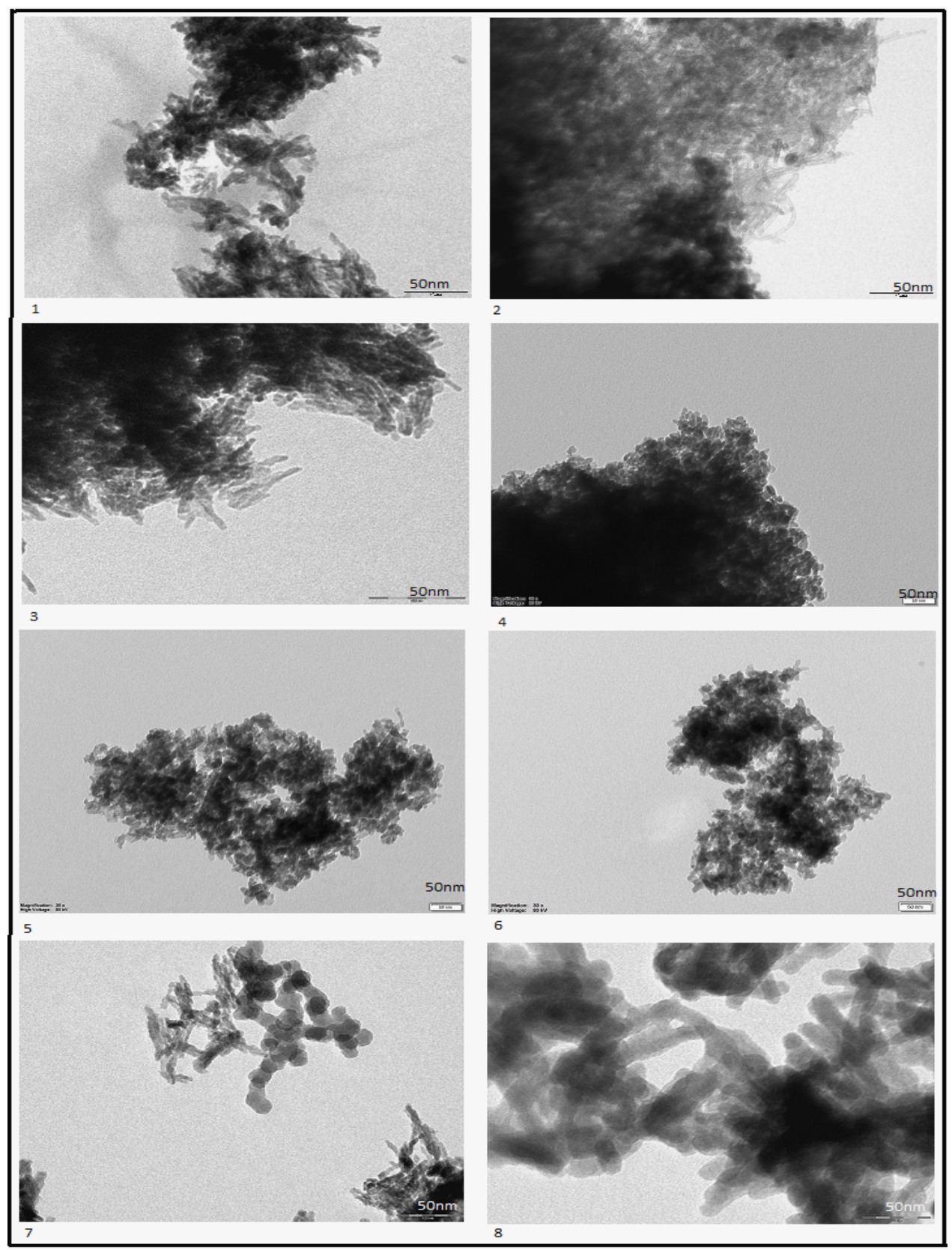

Figure 2. TEM images of: (1) HAP, (2) HAP-CNT, (3) HAP-GEL, (4) HAP-CS-10, (5) HAP-CS-15, (6) HAP-CS-20, (7) HAP+APTES, (8) HAP-GEL+APTES (The resolution of the images is $50 \mathrm{~nm}$ ) 


\section{$X R D$ measurements}

The composites were also analyzed by $x$-ray diffraction. There is no significant difference between the phase composition and crystallinity of HAP, HAP-GEL, HAP-CS and HAP-CNT. The peaks marked with star are characteristic for the hydroxyapatite. In case of all composites other phases besides HAP can not be identified (Figure 3).

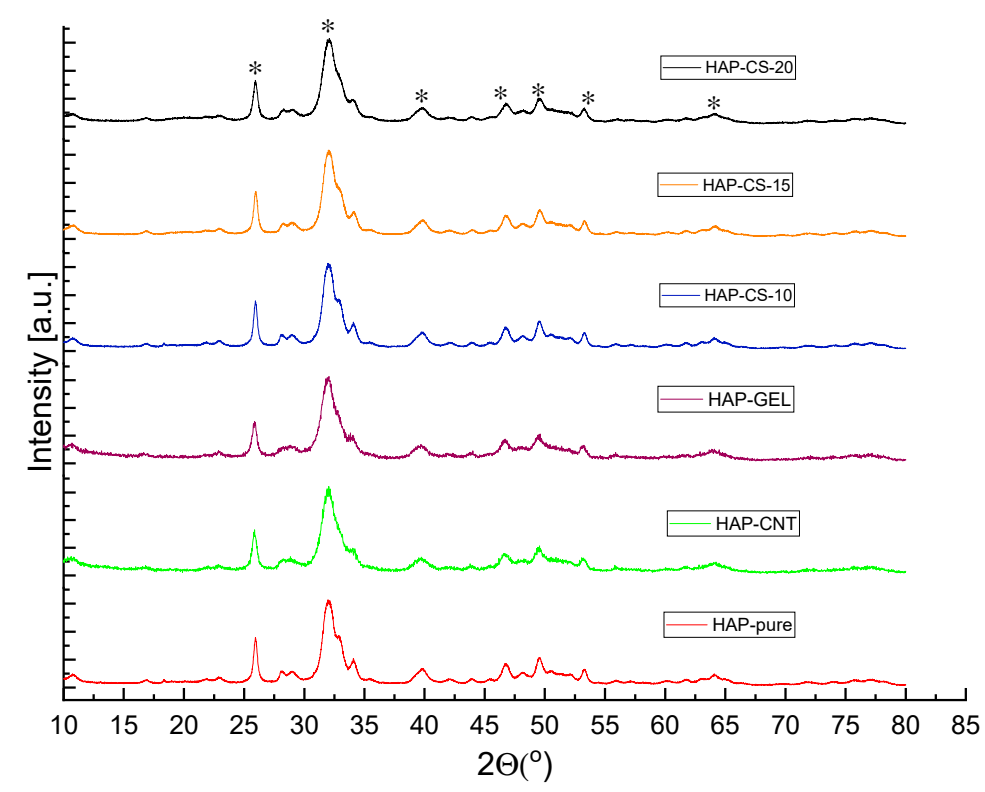

Figure 3. XRD measurements of HAP and HAP composites

\section{Immobilization of PcPAL on hydroxyapatite and its composites}

For the immobilization of the enzyme on the HAP and its composites obtained with carbon nanotubes and gelatin first a surface modification of the support material was achieved using aminopropyl triethoxy silan (APTES), followed by the addition of glycerol diglycidyl ether a crosslinker which was recently successfully used for the stable, covalent attachment of PcPAL on the surface of carbon nanotubes [21]. The enzyme was immobilized on the surface of the modified support material (Scheme 2A). For the HAP composites obtained with chitosan the direct linkage of the enzyme on the support material 
was achieved by using GDE (Scheme 2B). For control experiments also the adsorption of the enzyme on the surface of HAP was achieved. The obtained products were characterized by reproducibility (immobilization reactions were performed in duplicate) and high immobilization yields (Table 1.)
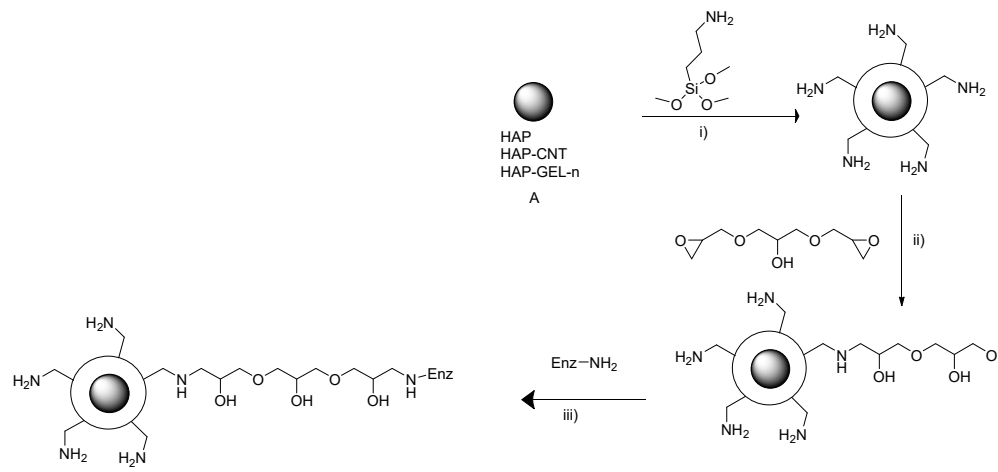

A
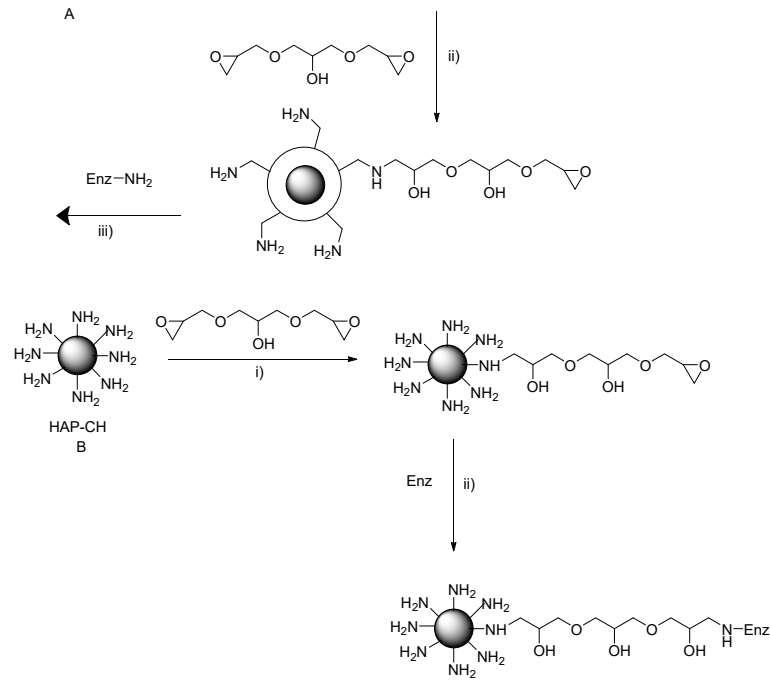

Scheme 2. Immobilization of PCPAL on A. HAP, HAP-CNT and HAP-GEL, i) APTES in EtOH, ii)GDE in EtOH, iii) PcPAL in Tris buffer, $0.1 \mathrm{M}$, pH 8.8 and B HAP-CH, i) GDE in EtOH, ii) PcPAL in Tris buffer, $0.1 \mathrm{M}, \mathrm{pH} 8.8$

Table 1. Immobilization yield of the enzyme preparations

\begin{tabular}{|c|c|}
\hline $\begin{array}{c}\text { SUPPORT } \\
\text { MATERIAL }\end{array}$ & $\begin{array}{c}\text { IMMOBILIZATION } \\
\text { YIELD (\%) }\end{array}$ \\
\hline HAP & 99 \\
\hline HAP-CNT & 99.9 \\
\hline HAP-GEL & 99.7 \\
\hline HAP-CS-10 & 91.9 \\
\hline HAP-CS-15 & 99.6 \\
\hline HAP-CS-20 & 92.4 \\
\hline HAP-ADS & 99.6 \\
\hline
\end{tabular}


Biocatalytic behavior of the obtained enzyme preparation in the ammonia elimination reaction from L-phenylalanine

The biocatalyst obtained by adsorption and by the covalent attachment of PCPAL on the HAP and HAP composites were tested in the ammonia elimination reactions from L-phenylalanine. The highest activity was achieved using the enzyme preparation obtained by HAP with $15 \%$ chitosan as support material (Table 2, entry 6), where the conversion was comparable with the conversion of the reaction catalyzed by the native enzyme (Table 2, entry 1 ), followed by HAP (Table 2, entry 2) and HAP-GEL (Table 2, entry 4). The lowest enzyme activity was achieved using HAP-CNT as biocatalyst (Table 2, entry 3). In order to further increase the conversion rates, different chitosan content was used as additive in the HAP. But by increasing or decreasing the chitosan content above or under $10 \%$, the enzyme activity decreased dramatically (Table 2, entry 5 and 7 ). The adsorbed enzyme preparation also showed high enzymatic activity (Table 2 , entry 8 ).

Table 2. Conversion of the reactions catalyzed by the immobilized PCPAL on HAP and HAP composites (rt, 22h)

\begin{tabular}{|c|c|c|}
\hline ENTRY & $\begin{array}{c}\text { ENZYME } \\
\text { PREPARATION }\end{array}$ & CONVERSION (\%) \\
\hline $\mathbf{1}$ & PCPAL & 98.5 \\
\hline $\mathbf{2}$ & HAP & 87.9 \\
\hline $\mathbf{3}$ & HAP-CNT & 77.7 \\
\hline $\mathbf{4}$ & HAP-GEL & 80.8 \\
\hline $\mathbf{5}$ & HAP-CS-10 & 49.5 \\
\hline $\mathbf{6}$ & HAP-CS-15 & 98.1 \\
\hline $\mathbf{7}$ & HAP-CS-20 & 53.97 \\
\hline $\mathbf{8}$ & HAP-ADS & 72.6 \\
\hline
\end{tabular}

Next, the reusability of the best performing enzyme preparations (HAP-PAL, HAP-CS-15-PAL, HAP-GEL-PAL, HAP-CNT-PAL, HAP-ads-PAL) was tested in repeated batch cycles. In case of all preparations the enzyme activity showed a decreasing tendency. The most stable enzyme preparation in the reusability test was the one obtained using HAP as support material, followed by the HAP-CS-15. In case of the HAP-GEL the first three cycles show a stability in the enzyme activity, followed by a drastic decrease. 
The less efficient biocatalyst proved to be the one obtained with HAP-CNT. The enzyme adsorbed on the surface of the support material showed a drastic decrease at the second reuse, the obtained conversion being only $14 \%$. This could be due to the leaking of the enzyme from the support material when immobilized by adsorption (Figure 4).

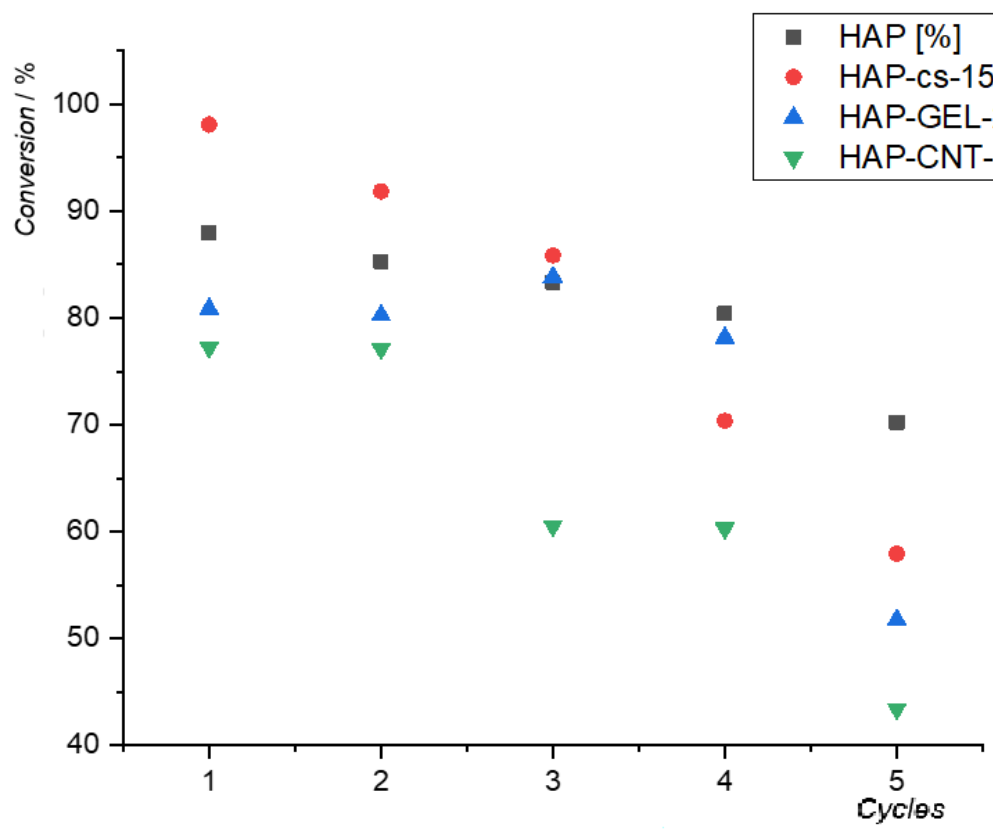

Figure 4. Reusability of the best performing immobilized enzyme preparations ( $\mathrm{rt}, 22 \mathrm{~h})$

Time-course profile

The time course profile of the ammonia elimination reactions from L-1 mediated by the two best performing enzyme preparations (HAP-PAL and HAP-CS-15-PAL) was investigated. Samples were withdrawn from the reaction mixtures after $1,2,4,7$, and 24 hours. In both cases an almost linear increase of conversion can be observed, however, in case of HAP-PAL the maximum conversion (91\%) was achieved faster (Figure 5). 


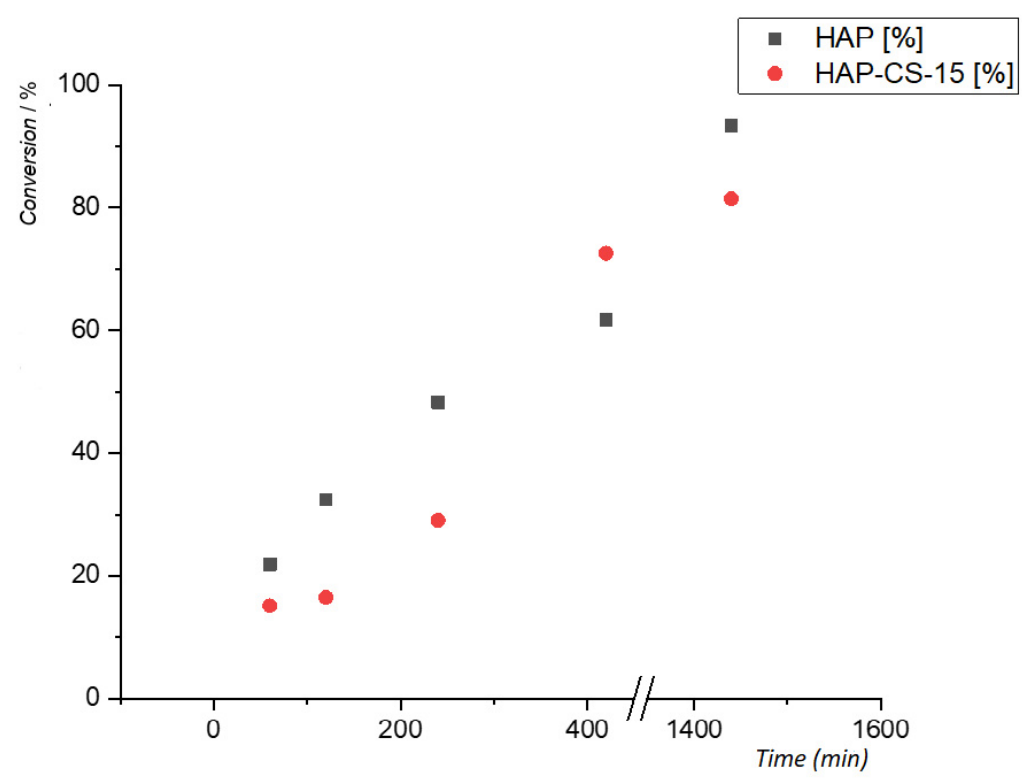

Figure 5. Time course profile of the reactions catalyzed by HAP-PAL and HAP-CS-15-PAL

\section{CONCLUSIONS}

This study demonstrates that hydroxyapatite and its composites obtained with carbon nanotubes, gelatin, and chitosan can be used as support material for the immobilization of phenylalanine ammonia lyase. The support materials were obtained by coprecipitation method and were characterized by transmission electron microscopy, laser diffraction particle size analyzer and XRD measurements. The obtained nanoparticles were further used for the immobilization of phenylalanine ammonia lyase. The nanobioconjugates were tested in the ammonia elimination reaction from L-phenylalanine. The most durable immobilized enzyme preparations were HAP-CS-15-PAL and HAP-PAL. The highest conversion rates were obtained with HAP-CS-15 $(98,1 \%)$, while in the reusability studies HAP-PAL had the best performance, it maintained more than $80 \%$ of its initial activity even after 5 cycles of reuse. Although these enzyme preparations show lower catalytic activity then other PCPAL preparations previously obtained, by further optimization procedures hydroxyapatite could be a promising alternative as support material for the immobilization of PAL. 


\section{EXPERIMENTAL SECTION}

\section{Materials}

\section{Enzyme}

Phenylalanine ammonia-lyase from parsley (PCPAL) was overexpressed in E. coli and purified according to the method described by Dima et al[34]

\section{Chemicals}

Single walled carbon nanotubes were purchased from Chengdu Organic Chemicals Co. Ltd (Chengdu, China). All other reagents were of analytical grade (Merck, Germany) and used without further purification. The technical grade solvents were dried and/or freshly distilled prior to use.

\section{Equipments}

Transmission electron microscopy (TEM) was performed using an automatic H-7650 TEM, Hitachi (Tokyo, Japan) with accelerating voltage 40-120 $\mathrm{kV}$, zoom 200x-600000x, by dipping a holey-carbon TEM grid into a suspension of the immobilized enzyme. Sample was imaged using an Olympus KeenView G2 camera, transmission electron microscope operating at $120 \mathrm{kV}$.

For the Bradford protein assay, an 8453 UV-Vis spectrophotometer, Agilent (Santa Clara, CA, USA) was used.

Ultrasonications during enzyme immobilization were performed in a Transsonic 460/H ultrasonic bath, Elma Schmidbauer $\mathrm{GmbH}$ (Singen, Germany) at $100 \mathrm{~W}, 40 \mathrm{kHz}$.

The shaking and incubation of enzymatic reactions was performed using a Titramax 1000 instrument, equipped with a heating module.

The particle size distribution was measured with a Shimadzu WING SALD-7101 (Japan).

The XRD analysis was performed on a Shimadzu XRD 6000 (Japan) using CuKa radiation at $40 \mathrm{Kv}, 30 \mathrm{~mA}$, at $\lambda=1.542 \AA . A$. X-Ray images were prepared for each material. The red lines indicates the caraceristic signs of the HAP crystals 25,8 32,05 39,84 46,78 49,53 53,13 63,97. The spectrum was identified by the ICPDS 09-0432 code in database.

The enzymatic reactions were monitored with an Agilent (Santa Clara, CA, USA) HPLC.

\section{Methods}

\section{Preparation of HAP and HAP composites}

Pure HAP and HAP-based NCs were prepared as previously described [35]. The used precursors were $\mathrm{Ca}\left(\mathrm{NO}_{3}\right)_{2}$ as a source of $\mathrm{Ca}^{2+}$ and $\left(\mathrm{NH}_{4}\right)_{2} \mathrm{HPO}_{4}$ as a source of $\mathrm{PO}_{4}{ }^{3-}$. An aqueous solution of $0.9 \mathrm{~mol} / \mathrm{L}\left(\mathrm{NH}_{4}\right)_{2} \mathrm{HPO}_{4}$ was added 
dropwise with a feed rate of $25 \mathrm{ml} / \mathrm{min}$, using a peristaltic pump, into a stirred aqueous solution of $1.5 \mathrm{~mol} / \mathrm{L} \mathrm{Ca}\left(\mathrm{NO}_{3}\right)_{2} \cdot 4 \mathrm{H}_{2} \mathrm{O}$, at room temperature. The appropriate quantities of additives, $1 \%$ carbon nanotube, $20 \%$ gelatin, were added to the $\mathrm{Ca}\left(\mathrm{NO}_{3}\right)_{2}$ solution while chitosan (10/15/20\%) was added to the $\left(\mathrm{NH}_{4}\right)_{2} \mathrm{HPO}_{4}$ solution. The $\mathrm{pH}$ was adjusted to 11 by adding $25 \%$ ammonia solution under constant stirring at room temperature. The suspension was matured for $22 \mathrm{~h}$, filtered and washed.

\section{Immobilization of the enzyme on HAP and HAP composites}

\section{Immobilization of PcPAL on HAP, HAP-GEL and HAP-CNT}

HAP and HAP composites (HAP-GEL, HAP-CNT 20mg) were added to a solution of APTES (120 mg in $5 \mathrm{~mL}$ ethanol, Scheme $2 \mathrm{~A}$ step $i)$ ). The obtained suspension was sonicated to avoid bundled HAP formation, and incubated at room temperature for 1 hour shaking at $1300 \mathrm{rpm}$. After 1 hour of incubation the reaction mixture was filtered and GDE $(100 \mathrm{mg}$ in $5 \mathrm{~mL}$ $\mathrm{EtOH}$ ) was added (Scheme 2A step $i i)$ ). The reaction mixture was incubated for 4 hours at room temperature shaking at $1300 \mathrm{rpm}$. After activation the sample was filtered. To the GDE activated support PCPAL $(2 \mathrm{mg}$ in Tris buffer, $0.1 \mathrm{M}, \mathrm{pH} 8.8$ ) was added and the reaction mixture was shaken at $1300 \mathrm{rpm}$ for 4 hours at room temperature (Scheme 2A step iii)). After the immobilization the resulted biocatalyst was filtered and washed with distilled water $(3 \times 10 \mathrm{~mL})$. The amount of PAL immobilized on the support material was determined from the total mass of the enzyme in the solution before the immobilization and in the unified filtrates after the immobilization (measured spectrophotometrically using the Bradford method).

\section{Immobilization of PcPAL on HAP-CS}

HAP-CS $(20 \mathrm{mg})$ was added to a solution of GDE $(100 \mathrm{mg}$ in $5 \mathrm{~mL}$ $\mathrm{EtOH}$ ) shaking at $1300 \mathrm{rpm}$ at room temperature for 4 hours (Scheme 2B step $i)$ ). The activated HAP-CS was filtered and PCPAL (2 $\mathrm{mg}$ in Tris buffer, $0.1 \mathrm{M}, \mathrm{pH} 8.8$ ) was added (Scheme 2B step ii)). The reaction mixture was incubated for 4 hours at $1300 \mathrm{rpm}$ at room temperature. The reaction mixture was filtered and the obtained enzyme preparation was washed with distilled water $(3 \times 10 \mathrm{~mL})$. The amount of PAL immobilized on the support material was determined from the total mass of the enzyme in the solution before the immobilization and in the unified filtrates after the immobilization (measured spectrophotometrically using the Bradford method).

\section{Immobilization of PcPAL on HAP-CS by adsorption}

HAP (20 mg) was added to a solution of PcPAL (2 mg in Tris buffer, $0.1 \mathrm{M}, \mathrm{pH} 8.8$ ). The reaction mixture was incubated for 4 hours at $1300 \mathrm{rpm}$ at room temperature. The reaction mixture was filtered and the obtained 
enzyme preparation was washed with distilled water $(3 \times 10 \mathrm{~mL})$. The amount of PAL immobilized on the support material was determined from the total mass of the enzyme in the solution before the immobilization and in the unified filtrates after the immobilization (measured spectrophotometrically using the Bradford method).

Ammonian elimination reaction from L-1 mediated by the obtained enzyme preparations

HAPs-PAL $(1 \mathrm{mg})$ was added to a solution of L-phenylalanine $(1,0.8$ $\mathrm{mg}, 4.7 \mathrm{mM})$ in Tris buffer $(0.1 \mathrm{M}, \mathrm{pH} 8.8,1 \mathrm{~mL})$. The resulting mixture was shaken $(1250 \mathrm{rpm})$ at room temperature for $22 \mathrm{~h}$. The reaction mixture was filtered and analyzed by high performance liquid chromatography.

Reusability of the immobilized enzyme preparations

For the recycling experiments the reactions were performed as described at the previous section. The enzyme was recovered from the reaction mixture after each cycle by centrifugation at $13400 \mathrm{rpm}$ for $1 \mathrm{~min}$ and washed with buffer solution $(3 \times 1 \mathrm{~mL})$ and reused in the following experiment.

The time course profile of the reactions

The time course profile of the reaction was obtained by performing the ammonia elimination reactions with reaction times of $1,2,4,7$ and $24 \mathrm{~h}$.

\section{ACKNOWLEDGMENTS}

This work was supported by a grant of the Romanian National Authority for Scientific Reasearch CNCS-UEFISCDI, project number PN-III-P2-2.1-PED2019-3664.

\section{REFERENCES}

1. L.M. Pera; M.D. Baigori; A. Pandey; G.R. Castro, Biocatalysis. Elsevier B.V., 2015.

2. R.A. Sheldon; S. Van Pelt, Chem. Soc. Rev., 2013, 42, , 6223-6235.

3. M. Hartmann; X. Kostrov, Chem. Soc. Rev., 2013, 42, 15, 6277-89.

4. C. Mateo; J.M. Palomo; M. Fuentes; L. Betancor; V. Grazu; F. López-Gallego; B.C.C. Pessela; A. Hidalgo; G. Férnandez-Lorente; R. Férnandez-Lafuente; J. M. Guisan, Enzyme Microb. Technol., 2006, 39, 2, 274-280.

5. W.C. Liu; H.Y. Wang; L.C. Chen; S.W. Huang; C. Wu; R.J. Chung, Ceram. Int., 2019, 45, 5, 5668-5679.

6. R. Barabás; E. de Souza Ávila; L.O. Ladeira; L.M. Antônio; R. Tötös; D. Simedru; L. Bizo; O. Cadar, Arab. J. Sci. Eng., 2020, 45, 1, 219-227.

7. S. Mondal; G. Hoang; P. Manivasagan; H. Kim; J. Oh, Ceram. Int., 2019, 45, 14, 17081-17093. 
8. P. Yang; Z. Quan; C. Li; X. Kang; H. Lian; J. Lin, Biomaterials, 2008, 29, 32, $4341-4347$.

9. S. Mondal; U. Pal; A. Dey, Ceram. Int., 2016, 42, 16, 18338-18346.

10. J.S. Cho; D.S. Yoo; Y.C. Chung; S. H. Rhee, J. Biomed. Mater. Res. - Part A, 2014, 102, 2, 455-469.

11. K. Balani; Y. Chen; S.P. Harimkar; N.B. Dahotre; A. Agarwal, Acta Biomater., 2007, 3, 6, 944-951.

12. M. Li; P. Xiong; F. Yan; S. Li; C. Ren; Z. Yin; A. Li; H. Li; X. Ji; Y. Zheng; Y. Cheng, Bioact. Mater., 2018, 3, 1, 1-18.

13. R.K. Brundavanam; Z.T. Jiang; P. Chapman; X.T. Le; N. Mondinos; D. Fawcett; G. E. J. Poinern, Ultrason. Sonochem., 2011, 18, 3, 697-703.

14. J. Venkatesan; S. K. Kim, Mar. Drugs, 2010, 8, 8, 2252-2266.

15. L. Poppe; J. Rétey, Curr Org Chem, 2003, 7, 13, 1297-1315.

16. L. Poppe; J. Rétey, Angew. Chemie - Int. Ed., 2005, 44, 24, 3668-3688.

17. H. Ritter; G.E. Schulz, Plant Cell, 2004, 16, 12, 3426-3436.

18. A. Gunia-Krzyżak; K. Słoczyńska; J. Popiół; P. Koczurkiewicz; H. Marona; E. Pękala, Int. J. Cosmet. Sci., 2018, 40, 4, 356-366.

19. D. Weiser; L.C. Bencze; G. Bánõczi; F. Ender; R. Kiss; E. Kõkai; A. Szilágyi; B. G. Vértessy; Ö. Farkas; C. Paizs; L. Poppe, ChemBioChem, 2015, 16, 16, 2283-2288.

20. D. Weiser; A. Varga; K. Kovács; F. Nagy; A. Szilágyi; B.G. Vértessy; C. Paizs; L. Poppe, ChemCatChem, 2014, 6, 5, 1463-1469.

21. J.H. Bartha-Vári; M.I. Toşa; F.D. Irimie; D. Weiser; Z. Boros; B.G. Vértessy; C. Paizs; L. Poppe, ChemCatChem, 2015, 7, 7, 1122-1128.

22. K.H. Jang; K.B. Song; J.S. Kim; C.H. Kim; B.H. Chung; S. K. Rhee, Bioprocess Eng., 2000, 23, 1, 89-93.

23. C. Marzadori; S. Miletti; C. Gessa; S. Ciurli, Soil Biol. Biochem., 1998, 30, 12, $1485-1490$.

24. B. Wang; J.J. Zhang; Z.Y. Pan; X.Q. Tao; H. S. Wang, Biosens. Bioelectron., 2009, 24, 5, 1141-1145.

25. A. Fihri; C. Len; R.S. Varma; A. Solhy, Coord. Chem. Rev., 2017, 347, 48-76.

26. T.A. Dick; L.A. dos Santos, Mater. Sci. Eng. C, 2017, 77, 874-882.

27. M. Prakasam; J. Locs; K. Salma-Ancane; D. Loca; A. Largeteau; L. BerzinaCimdina, J. Funct. Biomater., 2015, 6, 4, 1099-1140.

28. R. Rajesh; N. Senthilkumar; A. Hariharasubramanian; Y. Dominic Ravichandran, Int. J. Pharm. Pharm. Sci., 2012, 4, SUPPL. 5, 23-27.

29. R. Munirathinam; J. Huskens; W. Verboom, 1-32, 2015.

30. C. Zhou; Q. Wu, Colloids Surfaces B Biointerfaces, 2011, 84, 1, 155-162.

31. M.R. Nikpour; S.M. Rabiee; M. Jahanshahi, Compos. Part B Eng., 2012, 43, 4, 1881-1886.

32. R. Barabás; M. Czikó; I. Dékány; L. Bizo; E. S. Bogya, Chem. Pap., 2013, 67, $11,1414-1423$.

33. Z. Xu; G. Qian; M. Feng, Results Phys., 2020, 16, 102991 ,.

34. N.A. Dima; A. Filip; L.C. Bencze; M. Olah; P. Satorhelyi; B.G. Vertessy; I.Poppe; C. Paizs, Studia UBB Chemia, 2016, 61, 2, 21-34.

35. E.S. Bogya; R. Barabás; A. Csavdári; V. Dejeu; I. Bâldea, Chem. Pap., 2009, $63,5,568-573$. 